Review

Jasmin Ćelić, Ph.D.

E-mail: jcelic@pfri.hr, Aleksandar Cuculić, Ph.D.

E-mail: cuculic@pfri.hr, Sanjin Valčić, MEE, E-mail: svalcic@pfri.hr, University of Rijeka, Faculty of Maritime Studies, Studentska 2, 51000 Rijeka, Croatia

\title{
A Comparative Analysis of Maritime Universities Websites
}

\begin{abstract}
Nowadays, the Internet, i.e. its leading services like the World Wide Web are unavoidable in communications, providing services and information sharing. Websites and a variety of Internet pages that make up the World Wide Web are the primary user interfaces for online business, providing information and promotional activities on the Internet. The rapid and progressive development of this medium has led to the fact that there is almost no maritime education institution without its own website, or at least a web page. The quality and success of the presentation via the Internet and the development of websites in a way to suit users' needs still remain a problem, not only for designers and managers but also for owners, representing an incentive for the analysis and research in the field of maritime colleges. In evaluating user interfaces, including websites, different approaches and methods are used where the usability, due to its widespread use, is most often considered as the main factor of quality. In this paper, usability factors of websites are analyzed using the questionnaire method and available online tools for 20 maritime universities worldwide and the obtained results are presented as well as recommendations for further researches.
\end{abstract}

Key words: Maritime Universities, Maritime faculties, website, human-computer interaction, usability 


\section{Introduction}

The development of maritime transport has caused the emergence of various specific forms of seafarers' education and training. Occupations related to seafaring require specific set of competences and it is logical for colleges to have developed where attendants can acquire the required knowledge, practical skills and the necessary experience. In Croatia, there are two faculties of maritime studies, three nautical schools, two departments for maritime studies, and a whole range of schools with programmes closely related to maritime transport and training centres for seafarers. The existence of all those institutions indicates how important the maritime education is in our country. Likewise, in all other countries where the maritime sector is of strategic importance, the development of maritime colleges is present and is primarily driven be the need for high quality personnel related to maritime professions.

Keeping up with time due to their important role in society, maritime colleges have been regularly promoted in order to remain recognizable, and to highlight their tradition and quality. This presentation was carried out in different ways, but generally a well known medium for transmitting audio and video information across population has been used. Thus, soon after the appearance of the Internet, and its most famous World Wide Web service in $1989^{1}$, world's leading maritime universities became part of this new unavoidable medium which quickly evolved into what we know today, and presented themselves to the general public through their websites.

Modern websites are the main user interfaces for online business [1], providing information and promotion activities [2] [3] [4] on the Internet. The rapid and progressive development of this medium has led to the fact that almost all maritime education institutions have their own website, or at least the web page. However, the quality and effectiveness of the presentation via the Internet and developing websites in a way to suit their users' needs still remain a problem, not only for designers and managers [5], but also for the owner. These are also the main reasons for making the appropriate analysis of higher maritime education institutions' websites, in order to develop recommendations for their improvement.

Seafarers' education as an unavoidable factor in the development of seamanship is a prerequisite for maritime professions whose attractiveness can be mirrored through the amount of income, especially in countries with relatively low living standards. The increase in the number of those interested in maritime professions should not affect the quality of education and the prestige of traditional maritime educational institutions.

The importance of maritime transport for global economy and development of associated services and technologies have crucial influence in maintaining and increasing the quality of maritime education. This is primarily recognized in the case of maritime universities and colleges whose common interests, based on preserving the

In Croatia after 1992. 
quality of seafarers' education and the recognition of their role in the globalization process, result in the formation of various associations. One of the most recognizable associations is the International Association of Maritime Universities (IAMU) and therefore the websites of its members have been chosen for the analysis.

\section{Criteria for website assessment and evaluation}

Guidelines for the design and development of user interfaces have emerged from results of the research within the scientific discipline called human-computer interaction (human-computer interaction - HCI) ${ }^{2}$. At the end of the 20th century, with the appearance of more powerful computers, these guidelines became increasingly important not only for hardware and software design, but also for web applications. One of the leading methodologies for designing user interface is certainly the user-centred design - UCD which appreciates the needs, experience and constraints of users. The same methodology is almost always used in the design of web interfaces, where the characteristics of website users are partially known, or almost completely unknown.

Good website design should enable fast, simple and effective interaction regardless of user's profile, knowledge and experience. Websites can be regarded as a sort of software product because in both cases a particular form of programming is used, so the same or similar methods are used to analyze their quality. Most authors dealing with the analysis and evaluation of websites are using quality models according to ISO standards (ISO / IEC 25010: 2011), McCall and Boëhm, and only a few are defining their own models.

Development of appropriate quality model for the web is a complex task since it is a type of service present on all computer platforms running on different operating systems and using different programming languages and databases. Therefore, the selection of relevant quality indicators and determination of their mutual relations represent a problem not yet completely resolved. It is very difficult to determine which measurements should be performed and the type of metrics to be used in order to analyze and evaluate all the relevant indicators.

Based on McCall [6] and Boëhm [7] quality models, Fitzpatrick and Higgins have created and presented their own quality model suited for websites analysis in 1998. [8]. Their model includes some of the HCI standards and is adapted according to statutory regulations. Alongside with the resulting set of 12 external and 5 internal quality factors, the model includes 5 more specific factors for websites:

- Visibility:

- traceability,

- retrieveability,

- ease-of-access;

The interdisciplinary scientific branch that studies the interaction between people (users) and computers, and includes research, planning and design of user interfaces. 
- intelligibility:

- legibility,

- audibility,

- comprehensibility;

- credibility:

- integrity,

- accuracy;

- engageability:

- navigability,

- interactivity,

- appeal;

- differentiation:

- speciality,

- identity.

They define differentiation as a strategic factor and other factors as external.

It should be emphasised that shortly after the presentation of this quality model, Fitzpatrick begins to advocate engageability as an essential quality attribute in the websites assessment in his dissertation, which represents the first serious attempt to change or supplement the established reflection on the usability as a basic attribute of quality. Usability as an attribute of quality, which is used for estimation of the extent to which the user can successfully, efficiently and pleasurably use a particular product (hardware, software, web interface) to achieve specific objectives in the given context, was introduced for the first time by Jakob Nielsen [9]. It is based on the idea that websites should be designed in such a way as to allow for simple, fast and effective interaction to the user. But not all the authors think that it is sufficient enough to consider only usability as a key factor contributing to website quality, because it does not include the functionality of websites which is independent of the quality factor. G. Gledec in his book [10] lists a number of other authors who analyzed the quality attributes appropriate for websites assessment. However, because of its widespread application, usability retains the leading role in the evaluation of user interfaces [11] and thus of websites.

Evaluation of usability is carried out through systematic procedures for acquisition of data, related to the interaction between the end user and the software product or system. The collected data are analyzed and evaluated in order to determine whether a product or system follows the principles of usability.

Evaluation of usability consists of three basic parts:

- capture of data on the basis of which the usability will be assessed - data can be subjective, such as customer satisfaction, or objective, such as the number of errors committed, the time of execution of tasks, the number of successfully solved problems, etc. 
- analysis and interpretation of data - identifying problems that can compromise the usability,

- critique - proposals and solutions for the identified problems.

Before the beginning of the evaluation, relevant objectives for choosing the appropriate method are set. It is necessary to determine the characteristics of potential users, and select a group of examiners who will best represent the sample of users by whom the software product will eventually be used.

The next step is the selection of metrics for evaluation. In accordance with the definition of usability, it is necessary to measure the extent of effectiveness, efficiency and satisfaction. Furthermore, based on previous knowledge, the usability evaluation methods should be determined.

Methods for the evaluation of usability can be classified into three basic groups:

a) usability testing methods [12][13][14][15][16] - testing methods provide information about the way users are using the system and the problems they are facing. Tests are carried out by performing the task prepared in advance at fully developed system or experimental versions. Results are recorded by the evaluator or with the aid of special software solutions, and the analysis results should show if any errors occurred during the task performing, their type and frequency, complexity of the execution of given tasks etc. These methods include the following: Think-aloud Protocol, Question-asking Method, Co-Discovery Learning, Performance Measurement, Remote Testing, Shadowing Method, Retrospective Testing, Coaching Method, Teaching Method and Eye tracking,

b) usability inspection methods [11][17] - usability evaluation by inspection methods show the extent to which a user interface is in compliance with usability standards and specifications. Inspection methods are contrary to the testing methods where the usability of user interface is evaluated by testing real users. The final grade in case of usability evaluation by inspection method depends entirely on the judgment of one or more experts who conducted the review. These methods include: Heuristic Evaluation, Cognitive Walkthrough, Feature Inspection, Pluralistic Walkthrough, Formal Usability Inspection, Consistency Inspection, Standards Inspection and review of the compliance with the guidelines,

c) usability inquiry methods [18][20][21] - the result of the inquiry methods is not the effectiveness or success of examiners, but their personal level of satisfaction observed from different points of view. Inquiry methods are also used during the user needs identification and after the completion of product development. These methods include: Inquiry Methods, Interviews, Focus Groups, Logging Actual Use, Proactive Field Study, Questionnaires, Surveys, Self-reporting Logs and Screen Snapshots. 
Regardless of whether the methods which include software solutions or persons ${ }^{3}$ (users, experts, designers, developers, etc.) are used for the purpose of evaluation, it is important to determine the appropriate tasks to be performed. The procedure costs are certainly a limiting factor, but there are also indispensable factors like evaluation time and evaluation methods used. Special attention should be paid to factors such as the number of people involved in evaluation and their characteristics (experience, level of knowledge about test topic, adaptability, gender, etc.), working environment, evaluation conducting process, computer equipment and internet connections quality, etc.

\section{Maritime universities websites analysis}

Websites analysis included five randomly selected representatives of maritime universities in four regions: Europe, Asia/Pacific, America and Africa/Eastern Europe. Generally, comparative analysis of internet portals, websites and web pages is a complex and demanding task dependent on available requirements and resources. Persons who conduct the evaluation and analysis usually have access only to externally targeted web sites and a limited amount of computing, human and other resources. Computer resources can also be further restricted by insufficient bandwidth, while the results of testing, inspection and inquiry are liable to subjective impression of a person who conducts them and to other specific human characteristics.

Websites analysis can be static (investigating the quality factors and satisfaction of standards) and dynamic (the amount of activity during a specific time interval, interaction with customers). The type of analysis and the accessories used depend on the type and purpose of websites, the users target group, technologies used, general importance and scope.

For the purpose of comparative analysis, two different methods were used. The first method is represented by a questionnaire compiled on the basis of existing questionnaires (SUS, Quiz and CSUQ [19]) and the authors' experience, and is divided into five sections: accessibility, visibility, and navigation, content and general impression. The questionnaire was available online on a specially created website, and filled-in by a group of 20 students. It contains 30 paragraphs with the corresponding Likert scale (Figure 1) where the lowest value is absolute disagreement and the highest one is absolute agreement with the statement. Value "0" shows that the examinee has no opinion or not enough information about the statement.

3 Often, these methods of evaluation are also called automatic and empirical. Together with these methods, J. Nielsen also cites formal methods which use precise models and formulas for calculating usability, and non-formal methods which are based on the skills and experience of evaluators. 


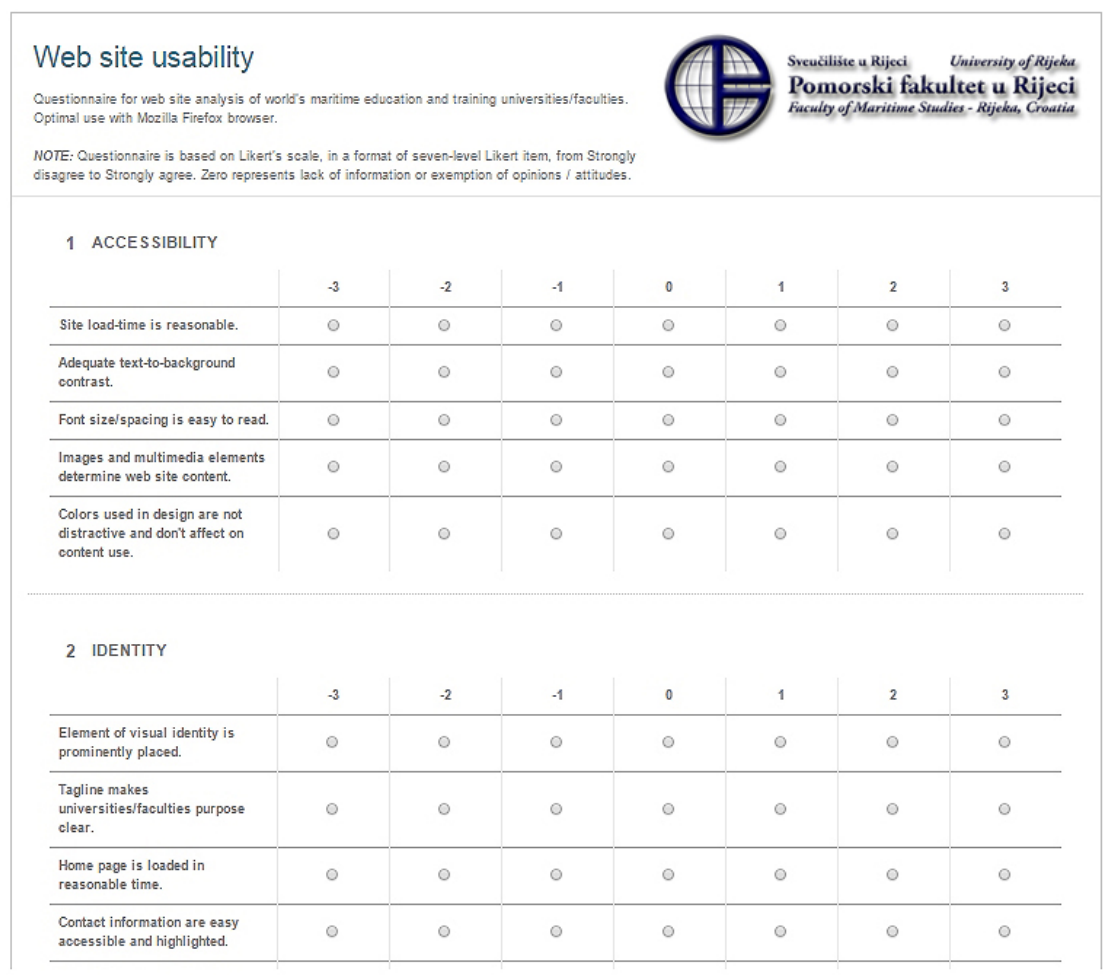

Figure 1. Questionnaire for the maritime universities websites analysis

The results show to what extent the factor represented by a particular statement has been taken into consideration during designing and creating of websites. The results confirm that maritime universities websites generally meet the defined standards for accessibility and navigation, and take care of the recognition and representing of the brand. However, the quality of the content and users' impression rather affects the usability of the observed website. Web sites are visually attractive, but relatively complex and not sufficiently simple to use as is shown on the graph in Figure 2. 


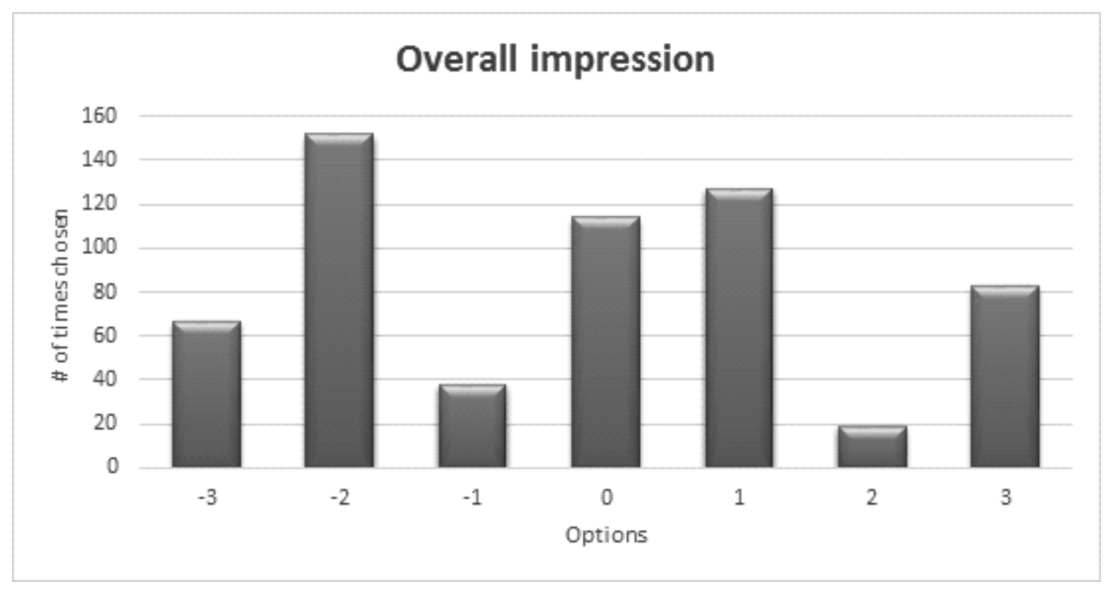

Figure 6. Display of consistency level within the web sites

The other method was based on static tests carried out with various software solutions and tools. The analysis resulted in four indicators: accessibility, satisfaction, marketing and technology. The indicator of accessibility is a measure of the availability for people with disabilities, but also for those who use mobile devices for access to the contents. The indicator of satisfaction is a measure of quality of users' experience with website. The marketing indicator represents the level of recognition and popularity, while the technological indicator represents the quality of the website design and performance. Results are shown in Table 1. 
Table 1. Websites quality indicators according to considered factors ${ }^{4}$

\begin{tabular}{|c|c|c|c|c|c|c|}
\hline & State & & Accessibility & Satisfaction & Marketing & Technology \\
\hline \multicolumn{7}{|l|}{ Europe } \\
\hline Web site 01 & Sweden & ell & 7,7 $\left.\right|_{\text {nll }}$ & 6,2 & 4,5 & 6,3 \\
\hline Web site 02 & Spain & olll & $8,1_{11}$ & 4,5 & 5,8 , ll & 6,8 \\
\hline Web site 03 & Bulgaria & elll & 4,0 all & 3,2 & 2,4 , & 3,4 \\
\hline Web site 04 & Denmark & ell & \begin{tabular}{l|l|l|}
7,2 & II \\
\end{tabular} & 4,4 & \begin{tabular}{l|l|l|l|l|}
2,8 & . \\
\end{tabular} & 5,8 \\
\hline Web site 05 & UK & loll & $5,0,1$ & 5,1 & $5,5,0]$ & 3,7 \\
\hline \multicolumn{7}{|c|}{ Asia, Pacific and Oceania } \\
\hline Web site 06 & India & alll & 1,3 , & 2,5 & 1,2 , & 2,9 \\
\hline Web site 07 & Philippines & all & 5,4 . & 4,4 & $2,5, \mathrm{ull}$ & 3,9 \\
\hline Web site 08 & Japan & ell & 7,3 all & 4,2 & 2,4 all & 5,6 \\
\hline Web site 09 & Vietnam & olll & $1,7, \mathbb{a}$ & 3,0 & $2,7 \mid$ & 2,6 \\
\hline Web site 10 & South Korea & ell & $7,1 a_{0}$ & 3,5 & 0,9 U. & 4,2 \\
\hline \multicolumn{7}{|l|}{ Americas } \\
\hline Web site 11 & Canada & elll & $4,6 \|_{01}$ & 5,4 & $4,5[\mathrm{all}$ & 4,5 \\
\hline Web site 12 & SAD & elll & 6,6 , & 3,3 & $5,3, \|$ & 3,5 \\
\hline Web site 13 & SAD & elll & 6,9 all & 5,1 & 5,9 . & 4,2 \\
\hline Web site 14 & Mexico & alll & 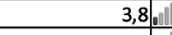 & 3,5 & 1,9 all & 3,3 \\
\hline Web site 15 & Venezuela & |oll| & $4,\left.9\right|_{10}$ & 2,8 & $\left.2,\left.4\right|_{11}\right]$ & 4,2 \\
\hline \multicolumn{7}{|c|}{ Africa / Eastern Europe } \\
\hline Web site 16 & Russia & elll & 4,0 all & 2,2 & 1,6 . & 1,9 \\
\hline Web site 17 & Egypt & oll & 6,8 .11. & 4,3 & 2,9 all & 6,9 \\
\hline Web site 18 & Iran & oull & 2,2 all & 2,0 & 0,6 , oll & 2,3 \\
\hline Web site 19 & Turkey & eill & $2,9 \mid \mathbb{a l l}$ & 2,5 & 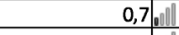 & 2,5 \\
\hline Web site 20 & Ukraine & alll & 3,3 . & 1,7 & $1,4 \ldots \mathbb{n}$ & 1,9 \\
\hline
\end{tabular}

Apart from numerical indicators, ranging from 0 to 10 , Table 1 also shows the icons that graphically represent the relevant value in percentage. In addition to these indicators, other indices were measured and are shown in Tables 2 and 3. The searching index shows how many times the search engines were indexed their databases with the relevant content of the observed website. Rankflex score is an indicator with the interval ranging from 0 to 10 and is dependent on the amount of accomplished traffic measured through search engines indexes, the amount of contained social services (Facebook, Twitter, etc.), keywords describing the web site, the applied technology, accessibility level, and privacy settings. The HubSpot marketing grade is built of various factors such as those affecting the search engine optimization, quality of utilization of various forms of social networking, presence in other people's social networks and alike. The MozRank indicator represents the logarithmic measure of web site authority and popularity and is similar to the Google's PageRank indicator. One of probably the most popular tools for website evaluation shows the position of the observed website as compared to others at the global and local levels, based on the traffic within the relevant time period. Also, it shows the number of users who visited a particular web site during the given time period, and the number of unique content views.

\footnotetext{
$4 \quad$ The maritime education institutions and Internet addresses were deliberately omitted.
} 
Table 2. Websites quality indicators obtained by various online tools

\begin{tabular}{|c|c|c|c|c|c|c|}
\hline & Search engine index & RankFlex score & HubSpot grade & mozRank & Alexa rank & Google PageRank \\
\hline \multicolumn{7}{|l|}{ Europe } \\
\hline Web site 01 & 14.000 & 54 . & 58 |all & 5,6, all & 1.205 .122 & 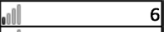 \\
\hline Web site 02 & 1.400 .000 & 62. & 80 . Ill & 6,4 & 15.289 & ill \\
\hline Web site 03 & 13.200 & 55 & 32 |all & 5,0 elll & 2.974 .759 & illl \\
\hline Web site 04 & 269 & 53 . & \begin{tabular}{l|l|l|l|}
47 & $|1|$ \\
\end{tabular} & 4,9 , tell & 24.887 .703 & all \\
\hline Web site 05 & 32.500 & 62 . & \begin{tabular}{|l|l|l|}
76 & .1l \\
\end{tabular} & $6,0,0.10$ & 88.609 & all \\
\hline \multicolumn{7}{|c|}{ Asia, Pacific and Oceania } \\
\hline Web site 06 & 927 & 43 . & 37. all & 4,6, all & 1.214 .345 & |lll| \\
\hline Web site 07 & 3.220 & 50 . & 39 | Inll & 4,8 ofll & 1.641 .978 & -11ll \\
\hline Web site 08 & 97 & 54 & 32 |all] & 5,3 oflll & 51.799 & alll \\
\hline Web site 09 & 181.000 & 44. & 39 all & 3,8 oflll & 279.398 & illl \\
\hline Web site 10 & 14 & 27 . & $37|a| l]$ & $3,8 \mid$, Ill & 1.204 .781 & . \\
\hline \multicolumn{7}{|l|}{ Americas } \\
\hline Web site 11 & 8.010 & 53 , & 53 . .1ll & 5,7 & 26.613 & wlll \\
\hline Web site 12 & 2.000 & 46 , & 69 all & 5,5 ofll & 1.623 .600 & elll \\
\hline Web site 13 & 28.900 & 31 . & $55 \mid$ |all & 5,3 anll & 664.525 & alll \\
\hline Web site 14 & 1.890 & 55 . & 38 . & 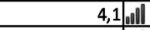 & 4.514.295 & -11ll \\
\hline Web site 15 & 96.200 & 52 . & $43 \mid, 1 \|$ & $4,3 \mid$ all & 1.955 .982 & |all \\
\hline \multicolumn{7}{|c|}{ Africa / Eastern Europe } \\
\hline Web site 16 & 525 & 55 . & 37 . 111 & 4,8 , flll & 3.169 .605 & |ell| \\
\hline Web site 17 & 445.000 & 52 . & 36 all & $4,9,1$ & 121.774 & ell \\
\hline Web site 18 & 22 & 36. & 24 |nlll & 4,1 , fill & 10.744 .163 & ell \\
\hline Web site 19 & 26 & 48 . & $31 \mid-11 \|$ & \begin{tabular}{l|l|l|}
4,1 & \\
\end{tabular} & 32.133 & |lll| \\
\hline Web site 20 & 339 & 43 & 30 .111) & \begin{tabular}{l|lll}
4,5 & \\
\end{tabular} & 23.586 & 正 \\
\hline
\end{tabular}

The Pingdom grade is the next indicator generated on the basis of different speed tests of web pages that makes up the observed website. Opening time shows the value in seconds necessary to open each of a web site home pages. In Table 3, there are also data on the number of unique visitors, site's popularity calculated by the country of origin (UVs rank), number of visitors per day (PPD) and number of pages that cite the evaluated website (VR). The number of unique visitors, UVs rank and PPD are not considered, because it is impossible to access the data for all Web sites.

Table 3. Other websites quality indicators

\begin{tabular}{|c|c|c|c|c|c|c|c|}
\hline & & Pingdom grade & Site load-time & Unique visitors & UVs rank & PPD & VR \\
\hline \multicolumn{8}{|l|}{ Europe } \\
\hline Web site 01 & all & 71 all & 3,94 ofll & 275 & $2.688 .315 \mid 0.1 \|$ & 904 all & 520 \\
\hline Web site 02 & alll & $86 \mid$ anl & 5,99 all & 13.083 & $117.251|0.0| \mid$ & 63.835 all & 23.233 \\
\hline Web site 03 & olll & $100 \mid 0.1$ & 23,10 & N/A & N/A & $\mathrm{N} / \mathrm{A}$ all & 275 \\
\hline Web site 04 & all & 80 . & \begin{tabular}{l|l}
1,83 & \\
\end{tabular} & $\mathrm{~N} / \mathrm{A}$ & \begin{tabular}{ll|l} 
N/A & Ill \\
\end{tabular} & \begin{tabular}{l|l|l|l|}
52 & \\
\end{tabular} & 145 \\
\hline Web site 05 & all & 80.011 & $1,66 \|_{11}$ & 2.786 & 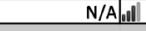 & 12.645.all & 2.745 \\
\hline \multicolumn{8}{|c|}{ Asia, Pacific and Oceania } \\
\hline Web site 06 & all & 83 . Ill & 3,32 & $\mathrm{~N} / \mathrm{A}$ & 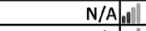 & 904,111 & 102 \\
\hline Web site 07 & all & 91.11 & 8,85 & $\mathrm{~N} / \mathrm{A}$ & $\mathrm{N} / \mathrm{A}_{\mathrm{e}} \mathrm{O}$ & 644 . & 344 \\
\hline Web site 08 & all & 84 . 011 & 3,06 & N/A & N/A & $\mathrm{N} / \mathrm{A}$. $1 \|$ & 220 \\
\hline Web site 09 & all & 79.11 & 11,76 & $\mathrm{~N} / \mathrm{A}$ & N/A $\mid$ all & $4.088 \mathrm{all}$ & 334 \\
\hline Web site 10 & olll & $70 \mid .10$ & 7,66 & $\mathrm{~N} / \mathrm{A}$ & N/A $|a| l \mid$ & $904 \mid$ alll & 10 \\
\hline \multicolumn{8}{|l|}{ Americas } \\
\hline Web site 11 & all & 78 .1.1. & 1,72 all & 4.761 & $\mathrm{~N} / \mathrm{A}$ & $\mathrm{N} / \mathrm{A}$ alll & 16.203 \\
\hline Web site 12 & alll & 88. & 7,98, & 6.849 & 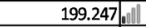 & 644 alll & 930 \\
\hline Web site 13 & all & $77 \mid$.11 & 1,17 , Ill & 13.473 & $114.443 .0 \mid$ & 1.640 , nll & 1.601 \\
\hline Web site 14 & allll| & 87 & 60,00 & N/A & \begin{tabular}{l|l|} 
N/A \\
\end{tabular} & 236 & 26 \\
\hline Web site 15 & all & 81 & 48,25 & $\mathrm{~N} / \mathrm{A}$ & N/A|alll & $644|.11|$ & 75 \\
\hline \multicolumn{8}{|c|}{ Africa / Eastern Europe } \\
\hline Web site 16 & all & 75 . Inl & 1,11 & $\mathrm{~N} / \mathrm{A}$ & N/A & 344 . 11 & 200 \\
\hline Web site 17 & olll & 63.01 & 6,08 all & 1.559 & 674.072 ofll & 9.062 oll & 840 \\
\hline Web site 18 & alll & 90.11 & 8,33 & $\mathrm{~N} / \mathrm{A}$ & N/A & 106 anll & 9 \\
\hline Web site 19 & all & 79.011 & 0,88 & N/A & N/A $\mid$ onl & \begin{tabular}{ll|l|l|l|}
33.847 & all \\
\end{tabular} & 14 \\
\hline Web site 20 & alll & 84.41 & 2,93 & $\mathrm{~N} / \mathrm{A}$ & N/A & 49.999|all| & 169 \\
\hline
\end{tabular}


The parameter that can be in a certain way used for the purpose of usability evaluation is an indicator derived from questionnaires that were used in the first method. The values of such indicators are shown in Table 4 for each website.

Table 4. Quality indicators obtained by the questionnaire method

\begin{tabular}{|c|c|}
\hline WEBSITE & $\begin{array}{c}\text { USABILITY } \\
\text { INDEX }\end{array}$ \\
\hline 1 & 0.99 \\
\hline 2 & 0.925 \\
\hline 3 & 0.53 \\
\hline 4 & 0.75 \\
\hline 5 & 0.525 \\
\hline 6 & 0.77 \\
\hline 7 & 0.77 \\
\hline 8 & 0.875 \\
\hline 9 & 0.52 \\
\hline 10 & 0.65 \\
\hline 11 & 0.57 \\
\hline 12 & 0.64 \\
\hline 13 & 0.59 \\
\hline 14 & 0.62 \\
\hline 15 & 0.67 \\
\hline 16 & 0.735 \\
\hline 17 & 0.9 \\
\hline 18 & 0.49 \\
\hline 19 & 0.67 \\
\hline 20 & 0.67 \\
\hline & \\
\hline
\end{tabular}

Based on the obtained results for each question in the questionnaire, parameters like mean, SD, and variance could be calculated. Also, the Univariate statistics and Pearson correlation among usability items or Cronbach's alpha reliability coefficients could be displayed [21]. 


\section{Conclusion}

For evaluation of websites, which can be divided according to their purpose into three basic types (advertising, commercial and informative), different criteria are used. Those criteria are usually accuracy, authority, objectivity, comprehensiveness and involvedness although many authors complement the various other criteria such as purposes, appropriateness, accessibility, clarity and the like. With the use of site choice, criteria depend among other things on available resources.

The criteria used in this study were selected on the basis of authors' experience in studying the Internet as one of the most influential media of today. The results obtained from the evaluation of maritime universities websites show that the quality of websites is usually determined by the technological level of the country of origin, and amount of respect for the Internet medium importance. The enthusiasm that some institutions are investing in the production of web sites and the level of monitoring the upcoming trends should be mentioned as well.

Further research in this area should be complemented with additional evaluation criteria, and the results should be compared with the results obtained by evaluating the Faculty of Maritime Studies in Rijeka, as one of the most respectable maritime universities. Also, the evaluation should include more subjects which would as far as possible exclude subjectivity. Selection of evaluators should include different profiles of participants, age group, gender, technical background and other factors. The evaluators should not be under any pressure, because in such a case the answers to questions will not represent acceptable real values. 


\section{Literature}

1. Straub, D., Watson, R.: "Research commentary: Transformational issues in researching IS and net-enabled organizations", Inform. System Res., 12(4), 2001, pp. 337-345.

2. Alba, S., Lynch, J., Weitz, B., Janiszewski, C., Lutz, R., Sawyer, A., Wood. S.: "Interactive home shopping: Consumer, retailer, and manufacturer incentives to participate in electronic markets", Marketing, 61(3), 1997, pp. 38-53.

3. Jarvenpaa, S., Todd, P.: "Consumer reactions to electronic shopping on the World Wide Web", Internal, J. Electronic Commerce, 1(2), 1997, pp. 59-88.

4. Schubert, P., Selz, D.: Web assessment: A model for the evaluation and the assessment of successful electronic commerce applications, Proc. $31^{\text {st }}$ Hawaii Internal, Conf. Systems Sci., 1998, Hawaii.

5. Price, M.: "What makes users revisit a Website?", Marketing News, 1997, pp. 12.

6. McCall, J., Richards, P., Walters, G.: "Factors in software quality", Vol. I-III, Rome Aid Defence Centre, 1977, Italy.

7. Boehm, B.: "Characteristics of software quality", Vol. 1 of TRW series on software technology, 1978, Amsterdam, Netherland.

8. Fitzpatrick, R., Higgins, C.: "Usable Software and its Attributes: A synthesis of Software Quality, European Community Law and Human-Computer Interaction", People and Computers XIII. Proceedings of HCI'98 Conference, London, UK, 1998.

9. Nielsen, J.: "Usability Engineering", Academic Press, 1993, Boston,

10. Gledec, G.: "Ergonomija u računarstvu", University of Zagreb, 2011, Zagreb,

11. Nielsen, J.: "Usability Inspection Methods", Conference companion on Human factors in computing systems, ACM, New York, 1994, pp. 413-414.

12. Lewis, C. H.: "Using the "Thinking Aloud" Method in Cognitive Interface Design" (Technical report), RC-9265, 1982.

13. Lewis, C. H., Rieman, J.: "Task-Centered User Interface Design: A Practical Introduction”, 1994. (dostupno na webu: http://hcibib.org/tcuid/chap-5.html)

14. Ericsson, K., Simon, H.: "Protocol Analysis: Verbal Reports as Data" (2nd ed.), MIT Press, 1993, Boston

15. Doubleday, A., Ryan, M., Springett, M., Sutcliffe, A.: "A comparison of usability techniques for evaluating design", Proceedings of DIS 97, 1997, New York, ACM, pp. 101-110.

16. Duchowski, A. T.: "Eye Tracking Methodology: Theory and Practice", Second edition, SpringerVerlag, 2007, London,

17. Nielsen, J., Molich, R.: "Heuristic evaluation of user interfaces", Proceeding ACM CHI'90 Conference, 1990, pp. 249-256.

18. Glasow, P. A.: "Fundamentals of Survey Research Methodology", The MITRE corporation, 2005.

19. Tullis, T. S., Stetson, J. N.: "UPA 2004 Presentation", Human Interface Design Department, Fidelity Center for Applied Technology, Boston, 2004.

20. Saeed, S., Baywa, I. S., Mahmood, Z.: "Human Factors in Software Development and Design", IGI Global, USA, 2015.

21. Wang, J., Senecal, S.: "Measuring Perceived Website Usability", Journal of Internet Commerce Volume 6, Issue 4, 2007, pp. 97-112. 
Jasmin Ćelić, Aleksandar Cuculić, Sanjin Valčić

\section{Komparativna analiza web sjedišta visokih pomorskih učilišta}

\section{Sažetak:}

Internet, odnosno njegovi vodeći servisi poput World Wide Weba, nezaobilazni su danas u komunikacijama, pružanju usluga i dijeljenju informacija. Web sjedišta i različite Internet stranice koje čine World Wide Web predstavljaju osnovna korisnička sučelja za mrežno poslovanje, pružanje informacija i promotivne aktivnosti na internetu. Brz i progresivan razvoj tog medija doveo je do toga da gotovo nema pomorskog učilišta koje ne posjeduje vlastito web sjedište ili barem internet stranicu. Kvaliteta i uspješnost prezentacije putem interneta te razvijanje web sjedišta na način da odgovaraju potrebama korisnika i dalje predstavljaju problem i to ne samo dizajnerima i menadžerima već i samim vlasnicima što je poticaj za analizu i istraživanje i u domeni pomorskih učilišta.

Za vrednovanje korisničkih sučelja, pa tako i web sjedišta, koriste se različiti pristupi i metode od kojih se, zbog svoje široke primjene, najčešće razmatra upotrebljivost kao osnovni čimbenik kvalitete. U ovom su radu analizirani čimbenici upotrebljivosti web sjedišta metodom upitnika i dostupnim online alatima za 20 visokih pomorskih učilišta širom svijeta te su prikazani dobiveni rezultati i dane preporuke za daljnja istraživanja.

Ključne riječi: visoka pomorska učilišta, pomorski fakulteti, web sjedišta, interakcija čovjeka i računala, upotrebljivost 